\title{
Human Resources Management in the Industrial Revolution 4.0: General and Polish Perspective
}

\author{
Katarzyna PIWOWAR-SULEJ \\ Wroclaw University of Economics, Wroclaw, Poland \\ katarzyna.piwowar@ue.wroc.pl
}

\begin{abstract}
The purpose of the article is to present the challenges faced by human resources management (HRM) in the context of changes regarding the Industrial Revolution 4.0. The holistic approach to this problem was used i.e. technology perceived from the perspective of two stakeholder groups. These are HR departments and the general body of employees. The paper is based on analysis of relevant literature studies in combination with scientific reflection. It discusses global changes as well as the nature of Polish market.
\end{abstract}

Keywords: Industrial Revolution 4.0, Human Resources Management, HR department.

\section{Introduction}

A thesis can be put forward that for the last decades the level of interest in the way people function in their workplaces has been increasing continuously. Therefore, managing people (human resources management, HRM) can be considered the key management area. As J. Latham [13] says, organizational systems do not exist without humans.

A dynamic era of change in the world of work will introduce the Industrial Revolution 4.0 (also referred to as the Cyber Revolution), which will be influenced by a range of new technologies and innovations resulting in driverless cars, smart robots, virtual reality, connected devices, artificial intelligence etc. The term Industry 4.0 refers to the Fourth Industrial Revolution and a German development program aimed at connecting people and machines to simplify all processes through digitalization [31]. The Industry 4.0 has four main characteristics, i.e. vertical networking with individualized production, horizontal integration across countries and continents, through-engineering and acceleration via exponential technologies [9]. The Industry 4.0 will bring new opportunities for work and have the potential of connecting billions more people in the web as well as drastically improving business efficiency [7]. These new technologies exert impact not only on work performance and efficiency, but also on people's attitudes and HRM processes. The new concept of eHRM (electronic human resources management) and HRM 4.0 does appear. E-HRM is defined as "the way of implementing HR strategies, policies and practices in organizations through a conscious and directed support of and/or with the full use of 
web-technology-based channels" [25]. In turn, adding the number "4.0" to the term of HRM means the digitalization of all HR processes [30].

The problems and influence of the Fourth Industrial Revolution are being touched up on in the subject literature. The existing publications usually focus only on some aspects of technological changes. Among them there are either labor market impacts or opportunities for IT tools implementation in HR processes [20]. The second case covers the following applications of modern technologies, referring to work-flow improvements (e.g. holiday applications processing), recruitment, training (elearning) or employer-employee communication (via the Intranet). The issue of eHRM is also mentioned. The purpose of this paper is to combine these two aspects of the Industrial Revolution 4.0, while anticipating new challenges for all the parties involved. The problem was discussed in more detail by means of answering the following research questions:

1) What are the implications of the Cyber Revolution for the employees?

2) What is the role of HR departments in the new digital world?

The analyzed problem was approached holistically, i.e. technology perceived from the perspective of two stakeholder groups. These are HR departments and the general body of employees. In order to provide answers for research questions the literature studies were conducted in combination with scientific reflection.

The first part of the paper discusses the effects of technological changes in terms of employees. These effects mainly result in the need for specific competencies and continuous professional development. The second part is focused on the influence of modern technologies on HR departments' work specificity, including the possibility of creating value-added services. The paper discusses both global changes and the nature of Polish market. Such factors as approx. 30 years lasting Polish free-market economy, the fall of central planning and restructuring of industry resulted in the adaptation of Western solutions in Polish HRM. The influx of foreign capital and the development of local IT systems supporting HR administration and salary accounting had their impact as well. One of Polish popular HR IT systems celebrated its 30th anniversary in 2017 [29]. New technologies were created simultaneously with the HR sector in Poland and have always had a real impact on its development.

\section{Implications of the Fourth Revolution for employees}

The beginning of all industrial revolutions took place within industry sector. In the Industrial Revolution 4.0 the commencement of a transformation process is not driven directly by the industry itself. The invention of social networks and intelligent devices used by employees should be considered as the main driving force. Today the development of these mutual interrelations functions as the driving force for the production sector development [26]. In the current economic reality, a model of "minute competitiveness" started to dominate offering prosperity opportunities only to these companies that faster and more efficiently collect and analyze streams of business information [12]. The production of material goods is accompanied by services based on communication with customers. Technological consulting is an 
example of such service. Success in selling services requires employees with advanced social skills.

The dynamic development of technology implies that employees have to deal with increasingly shorter product life cycles. The shelf life of specific technological knowledge becomes increasingly shorter. Such situation results in the need to unlearn some specific methods of performing tasks and to learn the new ones. Specialists from Boston Consulting Group say that by 2025 there will be about 350,000 new professions on the job market [16].

The implementation of Internet technology has also led to organizational changes towards virtualization. There are more and more organizations that occupy a small office space in relation to the number of employees and do not assign a desk to a specific person. Employees spend most of the week working on-line from home. As J.D. Lilly and D.W. Durr [15] say, many people now engage in work with few human interactions but there is an increased possibility of frustration with new, complex technology.

According to the authors of the report "Future work skills 2020", the main factors affecting the change of requirements for employees include e.g. increased usage of machines performing repetitive routine activities, the world moving towards programmable systems and the environment of new media. Based on the above characterized factors, it has been stated that employees will not be able to perform in the future as many repetitive tasks as they do now. Moreover, the list of ten competencies required from employees to "find themselves" in the future job market were identified. The list includes e.g.: transdisciplinary, novel and adaptive thinking, new media literacy, computational thinking and virtual collaboration [6]. In turn, the Association of Internet Industry Employers IAB Polska among the competencies related to the 4.0 revolution lists such features as: technological and IT skills or ability to acquire and analyze information [11].

According to the opinion presented in the subject literature by the year 2033 half of the existing professions will disappear. First of all, it will refer to such business areas as transport and logistics. Some of the professions related to office administration, insurance and finance services, or call center area are also "destined to extinction" [5]. The German Institute for Labor Market Research (Institut für Arbeitsmarkt- und Berufsforschung) states that the above described changes will increase the demand for high skilled employees along with reducing jobs for people with lower qualifications $[28,31]$. The OECD conducted comparative studies of changes in the labor market between the USA and the 28 countries of the European Union. These studies show that both the size of the medium-skilled jobs reduction and the increase of demand for higher qualifications are higher in the USA than in the European countries [28].

Based on the above statements it can be concluded that an employee of the future is a person involved in continuous learning. Modern technologies also influence learning methods. At this point it should be mentioned that the concept of "Learning 4.0" already exists and refers to the process of lifelong learning (from early childhood till retirement) with the help of modern technologies. Not only young people need to follow the changes. Low supply of new workforce in certain market areas produces 
the need for maintaining or even extending workforce by hiring the retirees. They also need to be able to work with modern IT tools.

\section{The role of HR department in the new digital world}

Subject literature presents various classifications of roles played by HR departments. It emphasizes that a general change of its role is observed nowadays, from a strictly administrative, through a development oriented one and even to a business partner function. The new role is determined by the previously mentioned, ongoing transformations in an enterprise milieu. The new needs of HR services' addressees keep emerging. Both the internal enterprise units and the external labor market ones represent the beneficiaries of activities carried out by HR specialists. The internal stakeholders of HR services are represented by an employer (management board), line and project managers and their subordinates [22].

Businesses must be alert to the changing environment and adapt their workforce planning as well as development strategies to ensure alignment with the future skill requirements. Strategic HR professionals might reconsider traditional methods for identifying critical skills along with selecting and developing talents. The workforce strategy for sustaining business goals should remain one of the most critical products of HR department work [6].

An external labor market can be the source for talent acquisition. Locating the right individuals and verifying their competencies will be a challenging task for HR specialists. IT tools have become indispensable in recruitment and selection (R\&S) process and facilitate the creation of a modern employer image [20]. The labor market participants - generation Y representatives - are fluent in modern technologies. The next generation - so called WWW - actively influences the content of commonly accessed Internet sites. This results in even greater expectations on an employer's part regarding modern technologies. Presently it is possible to conduct the entire R\&S process using virtual methods. The tools dedicated to on-line testing can be used to assess employees' competencies. This includes IQ as well as psychological testing. Elearning tools can also be applied at this point to test the level of candidates' proficiency [21].

Talents can be or even should be developed and nurtured internally, within the companies. The recently conducted research (April 2017) by IAB Polska in collaboration with Association of Marketing Communication (SAR) and Public Relations Enterprise Association shows that Poland lacks a unified and internally cohesive educational model. Polish universities are also not equipped to address the constant changes in communication methods in relation to new media development and the digital reality. Considering how important information technologies are for the quality of work, the practical educational model becomes absolute necessity [17]. HR departments are responsible for this model implementation inside companies. It is of great importance not only to enhance employees' development, but also to provide managers with the ongoing stream of technological news and their adoption benefits. Studies carried out by Ican Institute and published in 2017 show, that about $20 \%$ of 
managers from manufacturing companies in Poland have never heard of the Industry 4.0 idea and they are strictly focused on current operational tasks [10]. For such busy - people knowledge should be supplied in a condensed form to access it in the time which is suitable for them. In such situation it is worth using e-learning tools. Nowadays mobile devices offer extensive opportunities to learners, allowing them to improve their knowledge at all times, with no boundaries for education. HR departments should be aware that the trainings of the future do not apply to e-learning only (learning utilizing electronic technologies), but also m-learning (distant learning based on wireless technology) [18].

It is worth mentioning the need to invest in older employees. The research conducted by T. Broady, A. Chan and P. Caputi [3] has shown that negative stereotypes about older people being avoidant of technology and incapable of its usage are outdated. With proper encouragement, clear explanation of personal benefits and an appropriate time schedule, older people certainly have the potential to become equally effective in using technology on par with younger age groups. In the face of technological changes, it is also important to monitor staff satisfaction with the tools they are actually using - for example, by asking relevant questions in an annual employee opinion survey. Although the expectations of system users are collected during an IT project realization, the project itself and the role of IT department come to an end when the tool is implemented. HR department, in turn, is responsible for internal communication (including collecting feedback on possible system improvements).

As it has been mentioned before, modern technologies also influence the ways of how HR departments can work. E-HRM speeds up transaction processing, reduces information errors and advances the tracking and control of HR actions. It limits the repetitive paperwork, which HR specialists have to perform and also improves service delivery. By using e-HRM web-based technologies supervisors and personnel are made responsible for fulfilling the activities of $\mathrm{HR}$ role and thus a new $\mathrm{HR}$ architecture is created. M.L. Lengnick-Hall and S. Moritz [14, 27] identified three different levels of e-HRM, developed over time, which consist in one-way communication from organization to employees or managers through web-based channels. The second higher-level involves automation of transactions, workflow and even supply-chain integration, where paperwork is replaced by electronic input. Managers and employees can access databases, update information, search for the needed information and make decisions. The third and the highest level is focused on HR system transformation. The relevant levels are referred to as operational, relational and transformational [24] (see table 1).

Table 1. Three types of e-HRM

\begin{tabular}{lll}
\hline Type of e-HRM & Focus & Examples of processes \\
\hline Operational & Administrative functions & Payroll, personnel data \\
& Supporting business processes by means & Training, performance \\
Relational & of "soft" HR activities & management \\
Transformational & Strategic HR activities & Knowledge management \\
\hline
\end{tabular}


At this point it is worth emphasizing the limitations of operational digitalization work performed by HR departments resulting from the existing law in Poland. The procedure for keeping employee's personal records is determined by the resolution of the Minister of Labor and Social Policy dated 28th May 1996 on the scope of documentation kept by employers concerning matters related to employment relationship and the procedure for keeping personal records of employees (Journal of Laws of 1996, No. 62, item 286 as amended). The existing regulations do not provide for the possibility of keeping personal files in an electronic form. This requires from HR departments to collect and store documents in the traditional paper form. An amendment to the law is currently being in consultations. Despite announcements, the draft of amendments was not implemented in June 2017 (and even in December 2017) [32].

According to the latest forecasts, the global HR software market is expected to grow in the years to come by $2.4 \%$ annually and reach the value of $\$ 9.2$ billion by 2020 [17]. The so-called intelligent services, based on machine learning methodology, recognized as the higher generation of self-service solutions for employees and their supervisors are of extensive significance for the development of new HR processes' architecture. HR application, equipped with such functionality, is capable of taking appropriate steps in another module automatically by means of links between functional areas, based on a single transaction carried out in one place [4]. For example, when an employee's holiday is approved, during his/her absence, the system can automatically redirect his/her tasks to other employees within workflow processes, inform co-workers of the need to change dates of meetings with his/her participation, or postpone training reservations. All this happens within a system in a smart way, without the need for manual intervention, which greatly improves internal HR processes.

Social and mobile technologies offer numerous opportunities for HR to remain relevant and can reinvigorate personalized HR services. Over time, the relentless push for efficiency and economies of scale tended to make HR services less personal. Technology, however, keeps helping to reverse this trend by enabling HR's customers to develop actual relationships with real people in a virtual community, in a highly personal and interactive way. HR service centers can evolve into communities and HR portals can morph into social platforms. Social media capabilities enable employees to interact with HR and other parts of their organization, as well as with external vendors, alumni and colleges. Mobile devices help deliver on-demand service through easy-to-use apps [8].

It has been noted in the subject literature that the HR business partners' role is to create value for companies. Value creation takes place when organizations develop new ways of performing operations, using new methods [23]. R. Amit and C. Zott [1, 25] observe that in e-business new value can be created by the ways in which transactions are enabled. Organizations that invest in e-HRM aim at renewing their methods for implementing HR policies and practices, hoping for benefits such as improved efficiency and effectiveness. These benefits represent value-creating factors. C. Bowman and V. Ambrosini $[2,25]$ differentiate between two types of value creation at an organizational level: use value and exchange value. The first type 
refers to the specific aspect of a new job, product, or service in connection with users' requirements. It can be seen in the transformational functions of e-HRM usage. The second type, exchange value, is defined as the monetary amount realized after the exchange of a new task, service, or product. This type of value may arise from eHRM, mainly through cost reduction. At this point it is worth noting that the reduction of costs does not mean the reduction of jobs in HR departments. Parry [19] examined the hypothesis, which states that organizations with a lower ratio of HR staff to total employees would be more likely to use e-HRM. In fact, the use of eHRM does not lead to cost savings suggested by past literature in this field, not through the HR staff reduction.

\section{Conclusions}

The fourth industrial revolution changes the business model of companies. Modern industry is characterized by a high level of flexibility, optimization of production processes and better use of resources. These are the characteristics of enterprises that will determine their competitive advantage in the market. At the same time, the indicated changes affect the way employees perform their tasks. This, in turn, implies activities in the area of human resources management.

The subject literature provides a number of descriptions of the new reality, addressing various aspects of the incoming changes. This article highlights not only the possibilities for development of a new architecture of HR processes using IT tools and thus positioning HR departments as business partners, but also underlines impacts of changes on employees and the role of HR departments affected by these changes.

What new developments does the future hold? Undoubtedly, there is an ongoing need for employees' development, shaping their "skills of the future". The challenges for HR department entail attempts to keep up with the new trends while training managers. Additionally, new generations of employees are comming. They have enormous expectations when it comes to the company on line presence and people's responsiveness. The implementation of modern technologies under such conditions becomes a necessity.

Concluding the presented discussion it is worth emphasizing that the traditional forms of HR service delivery are still needed. It is most important to adjust work execution methods to the needs of stakeholders, i.e. employees. In some cases, employees can have limited access to IT tools, in some other cases they may prefer the old ways of communicating.

\section{References}

1. Amit, R., Zott, C.: Value creation in e-business. Strategic Management Journal, 22, 493520 (2001), DOI: 10.1002/smj.187.

2. Bowman, C., Ambrosini, V.: Value creation versus value capture: Towards a coherent definitione of value in strategy. British Journal of Management 11, 1-15 (2000), DOI: 10.1111/1467-8551.00147. 
3. Broady, T., Chan, A., Caputi, P.: Comparison of older and younger adults' attitudes towards and abilities with computers: Implications for training and learning. British Journal of Educational Technology 41 (3), 473-485 (2010).

4. CCNews: 4 trendy, które zdominują HR w 2017 roku, http://ccnews.p1/2017/01/23/4trendy-ktore-zdominuja-hr-w-2017-roku/, last accessed 2017/07/22.

5. Ciski, P.: Rozwiązania dla ludzi. Cyfryzacja procesów kadrowych kluczem do stworzenia organizacji przyszłości. Harvard Business Rewiev Poland, Special Edition „How to do IT. Technologie dla biznesu", 44-49 (2017).

6. Davies, A., Fidler, D., Gorbis, M.: Future Work Skills 2020, Institute for the Future for University of Phoenix Research Institute, Phoenix (2011).

7. De Lestrange, G.: What does the 'fourth industrial revolution' mean for HR?, https://www.cornerstoneondemand.co.uk/blog/what-does-\%25E2\%2580\%2598fourth-

industrial-revolution\%25E2\%2580\%2599-mean-hr\#.WVPTjojyiUk, last accessed 2017/07/28.

8. Deloitte: Human Capital Trends 2012. Leap Ahead, Deloitte Development LLC, Oakland (2012).

9. Deloitte: Industry 4.0. Challenges and solutions for the digital transformation and use of exponential technologies, Deloitte AG, Zurich (2015).

10. Gracel, J., Rodak, A.: Jak zbudować mapę drogowa do przemysłu 4.0. Harvard Business Rewiev Poland, Special Edition „How to do IT. Technologie dla biznesu”, 31-33 (2017).

11. Kolenda, P.: Badania i publikacje IAB Polska, In: Internet 2016/2017. Raport strategiczny, pp. 70-73, ICAN Institute, Warszawa (2017).

12. Kozłowski, T.: Gigabajty personalne. Personel 10, 46-48 (2007).

13. Latham, J.: Without people organizational system don't exist, http://johnlatham.me/psychology-stakeholders/, last accessed 2017/07/28.

14. Lengnick-Hall, M.L., Moritz S.: The impact of e- HR on the human resource management function. Journal of Labor Research 24, 365-379 (2003), DOI: 10.1007/s12122-003-10016.

15. Lilly, J. D., Durr, D.W.: Technology changes at work and employee reactions: The role of leader behavior. Human Systems Management 31 (3-4), 193-201 (2012), DOI: 10.3233/HSM-2012-0769.

16. Lorenz, M., Rüßmann, M., Strack, R., Lueth, K.L., Bolle, M.: Man and Machine in Industry 4.0. How will Technology Transform the Industrial Workforce Through 2025?, The Boston Consulting Group, München (2015)

17. MarketAnalysis.com: Human Resources (HR) Software Market Forecast 2015-2020, Tabular Analysis (2014), http://www.marketanalysis.com/?p=338, last accessed 2017/07/28

18. Ozuorcun, N.C., Tabak, F.: Is M-learning Versus E-learning or are They Supporting Each Other?. Procedia - Social and Behavioral Sciences 46, 299-305 (2012), DOI:10.1016/j.sbspro.2012.05.110.

19. Parry, E.: An examination of e-HRM as a means to increase the value of the HR function. The International Journal of Human Resource Management, 22 (5), 1146-1162 (2011), DOI: $10.1080 / 09585192.2011 .556791$.

20. Piwowar-Sulej, Pietroń-Pyszczek: EMPLOYER BRANDING USING MODERN TECHNOLOGIES, In: Kiełtyka L. (ed.), IT Tools in Knowledge Management in Organisations, Serie Monographs, No 211, pp. 79-91, Czestochowa University of Technology, Częstochowa (2011) 
21. Piwowar-Sulej, K.: Narzędzia IT w procesie doboru personelu - przesłanki oraz zakres stosowania (IT tools in recruitment and selection process - reasons for and scope of using). Management 1, 549-558 (2012).

22. Piwowar-Sulej, K., Król-Jasińska, A.: The role of HR department in Poland - indications for changes in business practice. Actual Problems of Economics 4 (166), 305-313 (2015)

23. Porter, M.: Competitive advantage: Creating and sustaining superior performance, The Free Press, New York (1985).

24. Ruel H., Bondarouk T., Looise J. C.: E-HRM: Innovation or irritation. Lemma Publishers, Utrecht (2004).

25. Ruel, H., Bondarouk, T., Van der Vald, M.: The Contribution of e-HRM to HRM $\begin{array}{lllll}\text { Effectiveness. Employee Relations } 29 \text { (3), 280-291 (2006), DOI: } & \end{array}$ 10.1108/01425450710741757.

26. Schuh, G., Potente, T., Wesch-Potente, C., Weber, A. R., Prote, J. P.: Collaboration mechanisms to increase productivity in the context of industrie 4.0. Procedia CIRP 19, 5156 (2014), DOI:10.1016/j.procir.2014.05.016.

27. Sekhar, Ch., Patwardhan, M.: Employee's Perception towards e-HRM Implementation: Indian Service Sector. Journal of Indian Management, July - September, 82-93 (2015).

28. Spermann, A.: Industrie $4.0=$ Mehr Roboter $=$ das Ende von Routinejobs? (Industry $4.0=$ More Robots = More Employment Polarization?). Wirtschaftspolitische Blatter 63 (2), 335-46 (2016)

29. Unit4 Polska, Historia HR w Polsce, czyli coś czego HR manager nie powinien przegapić, https://www.erpview.pl/rozwiazania_hr/historia_hr_w_polsce_czyli_cos_czego_hr_manager_nie_powinie n_przegapic.html, last accessed 2017/07/12.

30. Ursprung, S.: HRM 4.0: not yet with us! Summarizing the Personal Swiss, 22.04.2016, http://blog.jacando.com/en/hrm-4-0-noch-nicht-mit-uns-ein-besuch-an-der-personalswiss/, last accessed 2017/07/25.

31. Weber, E.: Industry 4.0 - job-producer or employment-destroyer?. Current Report $\mathrm{Nr} 2$, Institut für Arbeitsmarkt-und Berufsforschung (IAB), Nürnberg (2016).

32. Wrońska-Zblewska, K.: E-akta osobowe - zmiany coraz bliżej, https://www.portalkadrowy.pl/aktualnosci/eakta-osobowe-zmiany-coraz-blizej15799.html\#12388060, last accessed 2017/07/30. 